\title{
PENILAIAN EKSPRESI PROTEIN MDM2 DAN P53 SEBAGAI PREDIKTOR RESPON RADIOTERAPI PADA KANKER SERVIKS
}

\author{
Kun Mardiwati Rahayu ${ }^{1}$, Budiningsih Siregar' ${ }^{2}$, dan Iin Kurnia ${ }^{3}$ \\ ${ }^{1}$ Universitas Al Azhar Indonesia, ${ }^{2}$ Departemen Patologi Anatomi, Rumah Sakit Umum Pusat Cipto \\ Mangunkusumo, ${ }^{3}$ Pusat Teknologi Keselamatan dan Metrologi Radiasi (PTKMR), BATAN \\ Corresponding mail: kun_rahayu@uai.ac.id
}

\begin{abstract}
Cervical cancer is the second most common malignancy in Indonesia, and most of cases were already in advanced stage where radiotherapy is a tratement to given. Apoptosis is one of the markers for survival assessment of therapeutic response. In animal experiments MDM2 expression in various cell types to act as a survival factor by inhibiting the apoptotic function of p53 that is played by apoptosis can lead to malignant transformation and result in resistance to radiotherapy. Therefore, MDM2 is overexpressed due to alleged damage to p53 can also be used to assess the success of radiotherapy. This study aimed to assess the expression of MDM2 and p53 immunohistochemistry in cervical cancer and its relation to radiotherapy response. This study is a retrospective cross-sectional descriptive. The sample consisted of 23 cases of advanced cervical cancer were biopsied, 17 cases with complete response to radiation and 6 cases of partial radiation response. This study showed complete radiotherapy group MDM2 expression was found in $70.59 \%$ (12 cases) and p53 expression was found in $94.11 \%$ (16 cases), while the expression of MDM2, a partial response was found in 100\% (6 cases), while the expression p53 66.67\% (4 cases). MDM2 and p53 expression with SPSS 16 chi square test showed no association with response to radiotherapy in cervical cancer.
\end{abstract}

Keywords: Cervical cancer, expression of MDM2 protein, p53, radiotherapy Response

\section{PENDAHULUAN}

Kanker serviks merupakan kanker yang sering ditemukan terutama dinegara-negara berkembang dan merupakan penyebab kematian tersering pada perempuan. Setiap tahun, 530.000 perempuan diseluruh dunia terdiagnosis kanker serviks sementara di Indonesia berdasarkan data patologi pada tahun 2009 menempati urutan kedua dari 10 jenis kanker tersering, demikian pula data di Rumah Sakit Kanker Dharmais, sejak tahun 1993 hingga 2009 (WHO, 2008; BRKPDSPI, 2013; Aziz, 2009; BRMRSKD, 2009). Kematian akibat penyakit ini, sekitar 275.000 penderita, 88\% diantaranya terjadi dinegara-negara berkembang (Perhimpunan Dokter Spesialis Patologi, 2013). Hal ini karena pada umumya penderita datang dalam stadium lanjut yaitu 35,3\% pada stadium II dan 44,7\% pada stadium III (Aziz, 2009).

Pengobatan pada stadium lanjut adalah dengan radiasi (radioterapi). Tujuan utama dari radioterapi pada kanker adalah untuk mengurangi pertumbuhan tumor dan meminimalkan kerusakan pada jaringan normal (Liu, 2004). Respon sel tumor terhadap radioterapi berperan dalam penilaian keberhasilan pengobatan. Respon tersebut sangat bervariasi (Liu, 2004), beberapa penanda potensial dalam penilaian respon terhadap radioterapi kanker 
serviks antara lain adalah stadium, jumlah sel tumor, tipe histologi, invasi limfovaskuler, dan status kelanjar getah bening. Stadium dan ukuran tumor dianggap merupakan faktor penting dalam menentukan prognosis.

Aspek molekuler karsinogenesis menjelaskan peran protein p53 pada radiasi yaitu menginduksi terjadinya apoptosis. P53 sebagai supresor tumor juga merupakan faktor transkripsi dan mempengaruhi regulasi siklus sel, apoptosis, repair DNA, proses penuaan, dan angiogenesis. Aktivasi jalur sinyal p53 dependent merupakan salah satu respon sel kanker terhadap kerusakan DNA akibat radiasi pengion. Pada radioterapi kanker adanya apoptosis merupakan penanda ketahanan hidup dan penilaian respon terapi (Liu, 2004; Tanaka \& Harima, 2000).

Pertumbuhan tumor pada dasarnya merupakan ketidakseimbangan antara proliferasi dan kematian sel. Salah satu bentuk kematian sel yang mudah dideteksi dan sering dievaluasi adalah apoptosis. Apoptosis merupakan programmed cell death yaitu mekanisme homeostatis untuk memelihara populasi sel dalam jaringan tubuh Gerl \& Vaux (2005). Apoptosis dapat diaktifkan dan dinonaktifkan oleh berbagai gen. Deregulasi gen yang terlibat dalam aktivasi atau eksekusi pada proses apoptosis dapat menyebabkan radioresistensi sel (Tanaka \& Harima, 2000). Dalam aktivitasnya p53 membutuhkan induksi beberapa gen target termasuk MDM2 (Shangary \&Wang, 2008; Klein \& Vassilex, 2004).

MDM2 (Murine double minute 2) merupakan salah satu gen yang berperan penting dalam respon radiasi Perry (2004). Gen MDM2 pada awalnya diidentifikasi sebagai satu dari tiga gen (MDM 1, 2, dan 3) (Gerl \& Vaux, 2005; Iwakuma \& Lozano, 2003). Gen MDM2 pada manusia memiliki panjang 491 asam amino dan berinteraksi dengan domain $\mathrm{N}$ terminal pada $\alpha$ heliks transaktivasi p53 Shangary \& Wang (2008).

MDM2 bertindak sebagai faktor kelangsungan hidup pada berbagai jenis sel dengan membatasi fungsi apoptosis. MDM2 berfungsi sebagai antiapoptosis dapat diaktifkan oleh P13K untuk merangsang aktifitas protein kinase B atau Akt. Akt memphosphorisasi MDM2 dan mempromosikan translokasi ke inti sehingga dapat menghambat p53. Dengan demikian P13K meningkatkan fungsi kelangsungan hidup MDM2. Umpan balik (feed back loop) memastikan bahwa p53 sebagai mediator apoptosis tidak dapat dihilangkan oleh aktivitas P13K. p53 merangsang pembelahan dari Akt pada sel yang rentan mengalami apoptosis, hal ini menunjukkan bahwa p53 dapat menurunkan fungsi antiapoptosis MDM2 oleh mekanisme regulation down dari Akt pada keadaan yang sesuai (Perry, 2004).

Adanya mutasi titik mempengaruhi pengikatan p53 pada DNA dan mempengaruhi kapasitas protein transaktivasi (mempengaruhi ekspresi gen lain). Mutasi p53 merupakan perubahan genetik yang paling umum ditemukan pada kanker dan fungsi p53 akan hilang secara tidak langsung baik oleh ekslusi inti maupun interaksi dengan protein virus seperti pada kanker serviks, yaitu dengan mekanisme dimana protein E6 dari HPV-16 dan 18 akan mengakibatkan inaktivasi gen p 53 melalui mekanisme pengikatan yang disebut ubiquitin-dependent proteolytic pathway (E6AP) sehingga terjadi penurunan kadar protein p53 (wild type) (Troncone, et.al, 1998; Prayitno, 2005). Penurunan tersebut juga dapat terjadi akibat over ekspresi MDM2, sebaliknya p53 dapat mendegradasi MDM2. Onkogen MDM2 adalah target untuk aktivasi transkripsi oleh p53. Selain itu MDM2 juga menghentikan transaktivasi domain p53 dan menghambat aktivasi transkripsi yang tergantung p53. Diyakini fungsi normal MDM2 adalah membatasi lamanya "arrest" yang diinduksi oleh p53 (Iwakuma \& Lozano, 2003).

Penurunan kadar p53 pada keganasan telah terbukti meningkatkan resistensi terhadap efek sitotoksik dari kemoterapi atau radioterapi sedangkan ekspresi MDM2 dapat menekan fungsi p53 pada proses siklus sel, apoptosis dan respon terhadap kerusakan DNA. Radiasi pengion mengaktifkan p53 dan MDM2 yang mempengaruhi respon dalam radioterapi sehingga aktivasi MDM2 memainkan peran penting dalam mencegah kematian sel yang tidak 
terkendali akibat respon p53 dalam radiasi. Oleh karena itu, penghambat MDM2 dapat menjadi pendekatan yang efektif untuk meningkatkan terapi kanker sebagai mekanisme meningkatkan radiosensitivitas (Cao et al, 2005).

Bila terjadi degradasi fungsi p 53 maka proses karsinogenesis berjalan tanpa kontrol oleh p53. Oleh karena itu diduga gen MDM2 yang diamplifikasi akibat kerusakan p53 dapat juga dipakai sebagai indikator prognosis untuk menilai baik perkembangan lesi prekanker maupun keberhasilan terapi kanker serviks (Iwakuma \& Lozano, 2003; Orel \& Gordon, 2004).

\section{METODOLOGI PENELITIAN}

Desain penelitian ini adalah penelitian potong lintang deskriptif retrospektif yaitu dengan penilaian ekspresi protein MDM2 dan p53 serta hubungannya terhadap respon radioterapi.

\section{SUBYEK PENELITIAN}

Populasi terjangkau penelitian merupakan kasus kanker serviks stadium lanjut yang didiagnosis di Departemen Patologi Anatomi RSUP Cipto Mangunkusumo. Sampel merupakan bagian populasi terjangkau yang memenuhi kriteria inklusi dan ekslusi. Hasil respon radioterapi berasal dari Departemen Radioterapi RSCM.

\section{CARA KERJA}

\section{Metode : Immunohistokimia (IHK)}

A. $\quad$ MDM2

Sebelum dilakukan tahapan IHK, preparat diinkubasi pada suhu 500C selama 30-60 menit. Dilakukan deparafinasi yaitu preparat berupa blok parafin direndam dengan xylol sebanyak 3 kali masing-masing rendaman 5 menit. Setelah deparafinasi, dilakukan rehidrasi yaitu preparat direndam pada larutan alkohol dengan konsentrasi serial menurun yaitu 100\%, 95\%, 80\% dan 70\% masing-masing selama 5 menit. Sampel dicuci dengan aquadest sebanyak 3 kali masing-masing selama 5 menit. Selanjutnya dicuci dengan Phosphat buffer saline (PBS) sebanyak 3 kali masing-masing 5 menit kemudian diinkubasi dengan antigen retrieval pada suhu 960C selama 15 menit dan dilanjutkan pada temperatur ruangan selama 20 menit atau hingga suhu 500C. Cuci dengan PBS sebanyak 3 kali masing-masing 5 menit. Menandai posisi jaringan yang akan diamati dengan menggunakan pen marker. Tahapan selanjutnya mengikuti prosedur berdasarkan kit Novolink yaitu dengan menetesi preparat dengan blok peroksidase dan inkubasi pada suhu ruang selama 15 menit. Setelah inkubasi, cuci preparat dengan PBS sebanyak 3 kali masingmasing 5 menit. Lakukan inkubasi kembali dengan blok protein selama 15 menit dan cuci dengan PBS sebanyak 3 kali masing-masing 5 menit. Inkubasi dengan antibodi MDM2 (USBiological) pada suhu 40C selama semalam.

Setelah dilakukan inkubasi semalaman preparat dicuci dengan PBS sebanyak 3 kali selama masing-masing 5 menit dilanjutkan dengan inkubasi post primary selama 1 jam. Selanjutnya cuci dengan PBS sebanyak 3 kali selama

masing-masing 5 menit. Untuk mengikat antibodi sekunder diberikan Horse radish peroxidase (HRP) selama 60 menit pada suhu kamar dan bilas dengan PBS sebanyak 3 kali masing-masing 5 menit. Ikatan antigen antibody divisualisasikan dengan pemberian diaminobenzidine (DAB) pada suhu ruang selama 8 menit hingga terbentuk ikatan kromogen yang berwarna coklat. Preparat kemudian dicuci dengan aquadest dan dilakukan counter stain dengan hematoksilin selama 4 menit kemudian dicuci dengan air mengalir selama 20 menit.

Akhirnya dilakukan proses dehidrasi dengan alkohol serial dengan konsentrasi meningkat yaitu 70\%, 80\%, 90\%, 95\% dan 100\% masing-masing selama 5 menit. Selanjutnya dilakukan penjernihan dengan xylol sebanyak 3 kali 
masing-masing 5 menit dan dilakukan mounting dengan cover glass. Ekspresi MDM2 (warna coklat) pada inti sel dapat diamati dengan menggunakan mikroskop cahaya dengan pembesaran 40-400 kali selanjutnya dokumentasikan pada setiap pengamatan.

B. $\quad p 53$

Sebelum dilakukan tahapan IHK, preparat diinkubasi pada suhu 500C selama 30-60 menit. Dilakukan deparafinasi yaitu preparat berupa blok paraffin direndam dengan xylol sebanyak 3 kali masing-masing rendaman 5 menit. Setelah deparafinasi, dilakukan rehidrasi yaitu preparat direndam pada larutan alkohol dengan konsentrasi serial menurun yaitu 100\%, 95\%, 80\% dan 70\% masing-masing selama 5 menit. Sampel dicuci dengan aquadest sebanyak 3 kali masing-masing selama 5 menit. Selanjutnya dicuci dengan Phosphat buffer saline (PBS) sebanyak 3 kali masing-masing 5 menit kemudian diinkubasi dengan antigen retrieval pada suhu 960C selama 15 menit dan dilanjutkan pada temperatur ruangan selama 20 menit atau hingga suhu 500C. Cuci dengan PBS sebanyak 3 kali masing-masing 5 menit. Menandai posisi jaringan yang akan diamati dengan menggunakan pen marker. Tahapan selanjutnya mengikuti prosedur berdasarkan kit DAKO yaitu dengan menetesi preparat dengan blok peroksidase dan inkubasi pada suhu ruang selama 15 menit. Setelah inkubasi, cuci preparat dengan PBS sebanyak 3 kali masingmasing 5 menit. Inkubasi dengan antibodi p53 pada suhu ruang selama satu jam.

Preparat dicuci dengan PBS sebanyak 3 kali selama masing-masing 5 menit dilanjutkan dengan inkubasi Biotinylated link selama 30 menit. Selanjutnya cuci dengan PBS sebanyak 3 kali selama masing-masing 5 menit. Untuk mengikat antibodi sekunder diberikan Horse radish peroxidase (HRP) selama 30 menit pada suhu kamar dan bilas dengan PBS sebanyak 3 kali masing-masing 5 menit. Ikatan antigen antibody divisualisasikan dengan pemberian diaminobenzidine $(\mathrm{DAB})$ pada suhu ruang selama 8 menit hingga terbentuk ikatan kromogen yang berwarna coklat. Preparat kemudian dicuci dengan aquadest dan dilakukan counter stain dengan hematoksilin selama 4 menit kemudian dicuci dengan air mengalir selama 20 menit.

Akhirnya dilakukan proses dehidrasi dengan alkohol serial dengan konsentrasi meningkat yaitu 70\%, 80\%, 90\%, 95\% dan 100\% masing-masing selama 5 menit. Selanjutnya dilakukan penjernihan dengan xylol sebanyak 3 kali masing-masing 5 menit dan dilakukan mounting dengan cover glass.

Ekspresi p53 (warna coklat) pada inti sel dapat diamati dengan menggunakan mikroskop cahaya dengan pembesaran 40-400 kali selanjutnya dokumentasikan pada setiap pengamatan.

\section{Pembacaan Hasil Ekspresi MDM2 dan p53}

Penentuan ekspresi MDM2 dan p53 didasarkan pada hasil perhitung jumlah inti sel tumor yang positif (\%) pada 3 lapangan pandang berbeda dengan pembesaran 400x. Penilaian positif dibagi menjadi dua kelompok yaitu kelompok < $50 \%$ dan $>50 \%$ cut off > 5\% (Skomedal \& Kristensen, 1999; In Seo et al, 2001). Adanya immunoreaktifitas ditandai dengan adanya warna coklat pada sediaan yang gambarannya dibandingkan dengan kontrol positif dan kontrol negatifnya.

Ekspresi p53 yang didapat merupakan ekspresi p53 yang mutan dikarenakan waktu paruh p53 dalam sel cukup singkat. Sedangkan respon radioterapi diklasifikasikan sebagai berikut: 1) Respon komplit: tidak ada sisa tumor, fibrosis non spesifik, atau granulasi pada serviks, 2) Respon parsial : masih terdapat sisa tumor, teraba nodul pada serviks.

\section{ANALISA DATA}

Hasil penelitian ditabulasi dan disajikan dalam bentuk table serta dilakukan analisis secara statistik dengan 
uji Chi Square menggunakan Software SPSS ver 16. Probabilitas dianggap bermakna secara statistik apabila didapat nilai $\mathrm{p}<0,05$ dengan selang kepercayaan 90\% (Sopiyudin, 2009).

\section{HASIL PENELITIAN}

\section{KARAKTERISTIK SUBYEK PENELITIAN}

Dari 23 kasus yang memenuhi kriteria inklusi usia termuda 34 tahun dan tertua 70 tahun. Rerata usia adalah 53 tahun. Jumlah sampel terbanyak pada kelompok usia 51-60 tahun (52,17\%). Berdasarkan stadium sebagian besar kasus merupakan stadium III (82.61\%) sisanya stadium II. Derajat diferensiasi terbanyak adalah sedang 78.26\%, buruk sebanyak $17.39 \%$ dan baik sebanyak 4.35\%. Untuk ekspresi MDM2 didapat 78.26\% terekspresi positif dan $21.74 \%$ terekspresi negatif, sedangkan ekspresi p53 didapat hasil $86.96 \%$ terekspresi positif dan $13.04 \%$ terekspresi negatif. Berdasarkan tabel 2 didapat sebaran ekspresi protein MDM2 dan p53, terlihat bahwa pada kelompok respon parsial terdapat kelompok dengan ekspresi MDM2 positif dan p53 positif sebanyak 4 kasus, sedangkan pada kelompok respon komplit didapat ekspresi MDM2 positif dan p53 positif sebanyak 11 kasus.

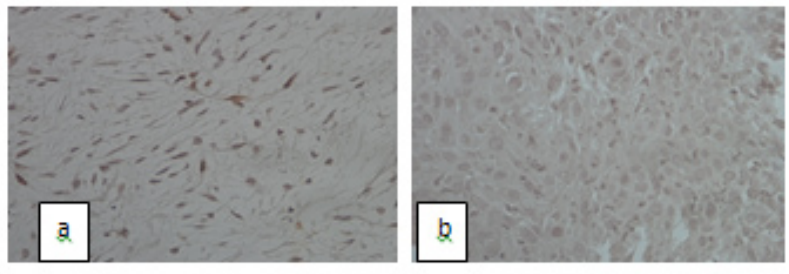

Gambar 1. (a) Ekspresi protein MDM2 pada kontrol positif, (b) kontrol negatif

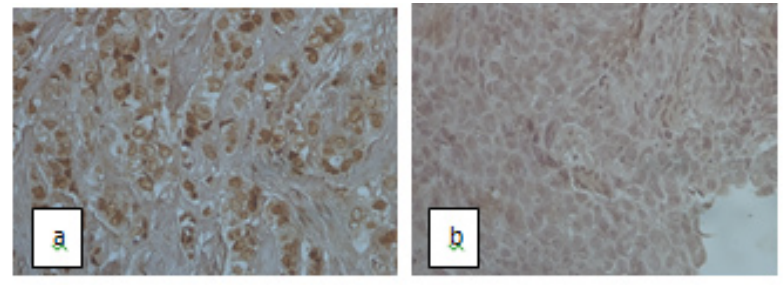

Gambar 2. (a) Ekspresi protein MDM2 pada kontrol positif, (b) kontrol negatif

\section{HASIL PEMERIKSAAN MDM2}

Hasil pulasan IHK menunjukkan bahwa ekspresi MDM2 dari 23 kasus 78.26\% terekspresi positif (gambar 3) serta 15 sampel (83.33\%) berada pada nilai positifitas 6-50\% (tabel 2). Berdasarkan tabel 3 didapat ekspresi MDM2 berdasarkan stadium, baik stadium IIB maupun IIIB sebaran ekspresi terbanyak pada kisaran $<50 \%$. Stadium IIB diperoleh 100\% (3 kasus) dan stadium IIIB diperoleh 80\% (12 kasus). Berdasarkan diferensiasi sel memiliki kecenderungan yang sama, diferensiasi baik, sedang dan buruk memiliki nilai positif terbanyak pada kisaran $<50 \%$. Diferensiasi baik 100\% (1 kasus), diferensiasi sedang 76.92\% (10 kasus) dan diferensiasi buruk 100\% (4 kasus). Untuk respon radiasi nilai positif berada pada kisaran $<50 \%$. Respon komplit $75 \%$ (9 kasus) dan respon parsial 100\% (6 kasus).

\section{HASIL PEMERIKSAAN P53 DAN RESPON RADIOTERAPI}

Ekspresi protein p53 dari 23 kasus 86.96\% terekspresi positif dan 13.04\% negatif (gambar 4). Berdasarkan stadium ekspresi p53 pada stadium IIB didapat 75\% ( 3 kasus) memiliki nilai positif dengan prosentase $>50 \%$,lain 
Tabel 1. Karakteristik subyek penelitian

\begin{tabular}{lrr}
\hline \multicolumn{1}{c}{ Karakteristik } & Rerata & \multicolumn{1}{c}{$\mathrm{n}(\%)$} \\
\hline Umur & 53 & \\
Stadium & & \\
II B & & $4(17.39)$ \\
III B & $19(82.61)$ \\
Derajat Diferensiasi Sel & $1(4.35)$ \\
Baik & $18(78.26)$ \\
Sedang & $4(17.39)$ \\
Buruk & \\
Respon Radiasi & $17(73.91)$ \\
Komplit & $6(26.09)$ \\
Parsial & \\
Ekspresi MDM2 & $18(78.26)$ \\
Positif & $5(21.74)$ \\
Negatif & \\
Ekspresi p53 & $20(86.96)$ \\
Positif & $3(13.04)$ \\
Negatif &
\end{tabular}

Tabel 2. Ekspresi protein MDM2 dan P53 serta respon radioterapi

\begin{tabular}{rlccc}
\hline No & No PA & $\begin{array}{c}\text { Ekspresi MDM2 } \\
(\%)\end{array}$ & $\begin{array}{c}\text { Ekspresi p53 } \\
\text { (mutan) }(\%)\end{array}$ & $\begin{array}{c}\text { Respon } \\
\text { radioterapi }\end{array}$ \\
\hline 1 & 1205698 & 20 & 30 & Parsial \\
2 & 1204817 & 29 & 24 & Parsial \\
3 & 1207116 & 10 & 0 & Parsial \\
4 & 1203778 & 12 & 75 & Komplit \\
5 & 1207327 & 60 & 90 & Komplit \\
6 & 1207723 & 5 & 16 & Komplit \\
7 & 1208092 & 25 & 75 & Komplit \\
8 & 1208644 & 56 & 17 & Komplit \\
9 & 1209015 & 15 & 71 & Komplit \\
10 & 1209134 & 20 & 5 & Komplit \\
11 & 1209986 & 25 & 55 & Parsial \\
12 & 1208700 & 42 & 18 & Komplit \\
13 & 1209812 & 3 & 44 & Komplit \\
14 & 1209998 & 34 & 52 & Komplit \\
15 & 1209024 & 15 & 0 & Parsial \\
16 & 1300156 & 20 & 31 & Komplit \\
17 & 1206331 & 5 & 75 & Komplit \\
18 & 1210319 & 60 & 40 & Komplit \\
19 & 1210130 & 5 & 38 & Komplit \\
20 & 1204695 & 30 & 72 & Parsial \\
21 & 1207875 & 11 & 60 & Komplit \\
22 & 1208581 & 20 & 24 & Komplit \\
23 & 1208162 & 4 & 75 & Komplit \\
\hline & & & & \\
\hline
\end{tabular}

halnya pada stadium IIIB kasus terbanyak berada pada kisaran nilai positif <50\%, sebanyak $56.25 \%$ ( 9 kasus). Berdasarkan diferensiasi, untuk diferensiasi baik diperoleh 100\% ( 1 kasus) berada pada kisaran $<50 \%$, diferensiasi sedang 50\% ( 8 kasus) pada nilai positif $<50 \%$ dan $50 \%$ ( 8 kasus) pada nilai positif $>50 \%$, untuk diferensiasi buruk diperoleh $66.67 \%$ ( 2 kasus) berada pada nilai positif $>50 \%$. Untuk respon radiasi komplit nilai positif berada pada kisaran $<50 \%$ sebanyak $50 \%$ ( 8 kasus) dan 50\% lainnya berada pada nilai positif $>50 \%$, dan respon parsial $66.67 \%$ ( 2 kasus) berada pada kisaran $<50 \%$ (Tabel 4 ). 

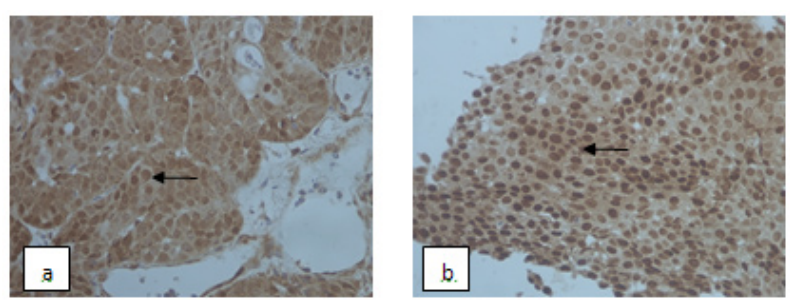

Gambar 3. (a) ekspresi MDM2 dengan nilai positif 25\%(<50\%), (b) ekspresi MDM2 dengan nilai positif $60 \%$ ( $>50 \%$ ), pada pembesaran 400x dan tanda panah menunjukkan ekspresi MDM2

\section{HUBUNGAN EKSPRESI MDM2 DAN P53 TERHADAP RESPON RADIOTERAPI}

Penilaian ekspresi MDM2 terhadap p53 disajikan pada tabel 5. Ekspresi MDM2 bernilai positif sebesar $78.26 \%$ dengan nilai positif terbanyak pada rentang $<50 \%$ sebanyak 15 kasus $(83.33 \%)$ dan ekspresi p53 didapat $86.96 \%$ dengan nilai positif tersebar pada nilai positif $<50 \%$ sebanyak $50 \%$ (10 kasus) dan $50 \%$ pada nilai positif $>50 \%$ (10 kasus). Nilai p berdasarkan uji Chi Square 0.328 tidak menunjukkan hubungan bermakna antara ekspresi MDM2 dan p53 (Tabel 5).

Tabel 3. Ekspresi MDM2 berdasarkan stadium, diferensiasi dan respon radioterapi pada kanker serviks

\begin{tabular}{ccccccr}
\hline \multirow{2}{*}{ Kriteria } & Nilai & \multicolumn{4}{c}{ Nilai Positif } & Jumlah \\
\cline { 4 - 7 } & Negatif & $\langle 50 \%$ & $>50 \%$ & $\mathrm{n}$ & Total \\
\hline \multirow{2}{*}{ Stadium } & IIB & $1(25 \%)$ & $3(100 \%)$ & 0 & $3(75 \%)$ & 4 \\
& IIIB & $4(21.05 \%)$ & $12(80 \%)$ & $3(20 \%)$ & $15(78.95 \%)$ & 19 \\
\hline \multirow{2}{*}{ Diferensiasi } & Baik & 0 & $1(100 \%)$ & 0 & $1(100 \%)$ & 1 \\
(Grade) & Sedang & $5(27.78 \%)$ & $10(76.92 \%)$ & $3(23.08 \%)$ & $13(72.22 \%)$ & 18 \\
& Buruk & 0 & $4(100 \%)$ & 0 & $4(100 \%)$ & 4 \\
\hline Respon & Komplit & $5(29.31 \%)$ & $9(75 \%)$ & $3(25 \%)$ & $12(70.59 \%)$ & 17 \\
Radioterapi & Parsial & 0 & $6(100 \%)$ & 0 & $6(100 \%)$ & 6 \\
\hline
\end{tabular}

Pada kasus dengan respon radioterapi komplit, positifitas MDM2 terbanyak berada pada kisaran <50\% yaitu $75 \%$ ( 9 kasus) dan $>50 \%$ sebanyak $25 \%$ ( 3 kasus) sedangkan p53 respon komplit 50\% ( 8 kasus) berada pada nilai $<50 \%$ dan $50 \%$ ( 8 kasus) berada pada nilai positif $>50 \%$. Untuk respon parsial ekspresi MDM2 terbanyak pada kisaran $<50 \%$ sebanyak 6 kasus (100\%) sedangkan untuk ekspresi p53 respon parsial sebanyak 50\% (2 kasus) berada pada kisaran $<50 \%$ dan $50 \%$ lainnya berada pada $>50 \%$ ( 2 kasus). Hubungan ekspresi MDM2 dengan respon radioterapi tidak menunjukkan hubungan yang bermakna $(\mathrm{p}=0.180)$ demikian halnya hubungan antara ekspresi p53 dengan respon radioterapi tidak menunjukkan kebermaknaan $(\mathrm{p}=1)$.

\section{PEMBAHASAN}

\section{KARAKTERISTIK SUBYEK PENELITIAN}

Pada penelitian ini didapat 52.17\% kasus pada rentang usia 51-60 tahun. Data yang sama juga didapat oleh Badan Registrasi Kanker Indonesia untuk kanker serviks secara umum ditemukan 61.10\% pada rentang usia 45-64 tahun.2 Pada penelitian ini didapat rerata usia 53 tahun, tidak berbeda jauh dengan hasil penelitian yang dilakukan oleh Romus, dkk didapat rata-rata usia penderita kanker serviks adalah 54 tahun dan kejadian diluar negeri yaitu 
rerata usia penderita 51.4 tahun (Ilhami, et al., 2013). Stadium terbanyak pada kasus ini adalah IIIB sebanyak 82.61\%, dengan derajat diferensiasi terbanyak adalah diferensiasi sedang $78.26 \%$, diferensiasi buruk $17.39 \%$ dan baik 4,35\%. Pilihan dalam pengobatan kanker serviks stadium lanjut adalah radioterapi dengan tingkat keberhasilan sebesar 70\% Angela et al., 2005). Menurut Nakano, et al., (2010) respon radioterapi dipengaruhi oleh stadium klinik, derajat diferensiasi sel, radiosensitifitas serta kualitas radiasi.

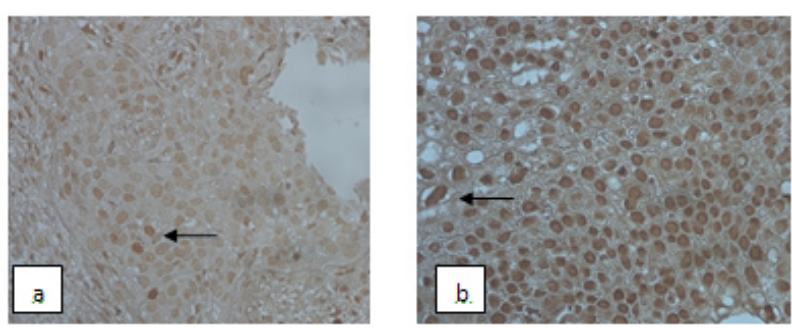

Gambar 4. (a) ekspresi p53 dengan nilai positif $16 \%(<50 \%)$ pada pembesaran $400 x$, (b) ekspresi p53 dengan nilai positif $90 \%$ ( $>50 \%)$ pada pembesaran 400x lihat tanda panah menunjukkan ekspresi p53

\section{EKSPRESI MDM2 PADA KANKER SERVIKS}

Pada penelitian ini jumlah kasus dengan ekspresi MDM2 positif 78.26\%, 76.92\% berdiferensiasi sedang, 78.95\% berada pada stadium IIIB. Diantara 18 kasus dengan ekspresi MDM2, 15 diantaranya juga menunjukkan ekspresi p53.

Ekspresi MDM2 lebih dari 50\% juga dilaporkan oleh Troncone, dkk dan Park, dkk (Troncone, et.al., 1998; InSeo et al., 2001). Dalam penelitian Troncone pada 31 sampel kanker serviks 20 kasus (64.15\%) terekspresi dan hasil rata-rata ekspresi MDM2 sebesar 11.13\%. Penelitian tersebut membagi kasus menjadi dua kelompok yaitu kelompok HPV positif dan kelompok HPV negatif. Ekspresi MDM2 pada kelompok HPV positif 12.6\% dan kelompok HPV negatif $10 \%$. Nilai ini secara statistik tidak menunjukkan kemaknaan terhadap ekspresi MDM2, namun ekspresi MDM2 berhubungan dengan ekspresi p53. Mereka menyimpulkan bahwa akumulasi p53 ditemukan pada setiap kasus kanker serviks akan berkaitan dengan ekspresi dari "downstream protein" seperti MDM2 (Troncone, et.al., 1998).

Tabel 4. Ekspresi p53 terhadap stadium, diferensiasi dan respon radioterapi pada kanker serviks

\begin{tabular}{|c|c|c|c|c|c|c|}
\hline \multirow{2}{*}{\multicolumn{2}{|c|}{ Kriteria }} & \multirow{3}{*}{$\begin{array}{c}\begin{array}{c}\text { Nilai } \\
\text { Negatif }\end{array} \\
0\end{array}$} & \multicolumn{3}{|c|}{ Nilai Positif } & \multirow{2}{*}{$\begin{array}{l}\text { Jumlah } \\
\text { Total }\end{array}$} \\
\hline & & & $<50 \%$ & $>50 \%$ & $n$ & \\
\hline \multirow{2}{*}{ Stadium } & IIB & & $1(25 \%)$ & $3(75 \%)$ & $4(100 \%)$ & 4 \\
\hline & IIIB & $3(15.79 \%)$ & $9(56.25 \%)$ & $7(43.75 \%)$ & $16(84.21 \%)$ & 19 \\
\hline \multirow{3}{*}{$\begin{array}{l}\text { Diferensiasi } \\
\text { (Grade) }\end{array}$} & Baik & 0 & $1(100 \%)$ & 0 & $1(100 \%)$ & 1 \\
\hline & Sedang & $2(0.11 \%)$ & $8(50 \%)$ & $8(50 \%)$ & $16(88.89 \%)$ & 18 \\
\hline & Buruks & $1(0.25 \%)$ & $1(33.33 \%)$ & $2(66.67 \%)$ & $3(0.75 \%)$ & 4 \\
\hline \multirow{2}{*}{$\begin{array}{c}\text { Respon } \\
\text { Radioterapi }\end{array}$} & Komplit & $1(5.89 \%)$ & $8(50 \%)$ & $8(50 \%)$ & $16(94.11 \%)$ & 17 \\
\hline & Parsial & $2(33.33 \%)$ & $2(50 \%)$ & $2(50 \%)$ & $4(66.67 \%)$ & 6 \\
\hline
\end{tabular}

Park, dkk mendapatkan ekspresi MDM2 dengan cut off serupa sejumlah 66.67\% kasus kanker serviks. Mereka melakukan pengamatan seperti halnya Troncone,dkk membagi kelompok HPV negatif dan HPV positif. Tingginya ekspresi MDM2 pada kedua kelompok HPV ini mengindikasikan bahwa terdapat proses karsinogenesis dimana protein p53 akan mempengaruhi protein-protein lain termasuk MDM2 (In-Seo et al., 2001). Skomedal, 
et al., (1999) mendapatkan ekspresi MDM2 pada 35\% kasus kanker serviks dan menunjukkan koekspresi yang bermakna dengan p53. Pada penelitian tersebut juga disimpulkan bahwa MDM2 diduga dapat melindungi degradasi protein TP53 oleh HPV.

Penelitian lain yang dilakukan oleh Kersemaekers et al., (1999) menunjukkan ekspresi kuat pada 13\% dari 112 kasus kanker serviks berdasarkan penilaian skor semikuantitatif dengan menghitung prosentase sel dan intensitas warna pada pulasan IHK. Pada penelitian tersebut hanya 17 kasus menunjukkan ekspresi MDM2 kuat, dan berhubungan dengan ekspresi p53. Bila ekspresi p53 kuat maka ekspresi MDM2 juga kuat. Hasil ini mengindikasikan bahwa feedback loop dideregulasi dan p53 tidak didegradasi oleh MDM2.

Tabel 5. Nilai positif ekspresi MDM2 dengan p53 pada kanker serviks

\begin{tabular}{lccccc}
\hline \multirow{2}{*}{ Kriteria } & \multirow{2}{*}{$\begin{array}{c}\text { Nilai } \\
\text { Negatif }\end{array}$} & \multicolumn{3}{c}{ Nilai Positif } & \\
\cline { 3 - 5 } & & $<50 \%$ & $250 \%$ & $\mathrm{n}$ & $\begin{array}{c}\text { Jumlah } \\
\text { Total }\end{array}$ \\
\hline MDM2 & $5(21.74 \%)$ & $15(83.33 \%)$ & $3(16.67 \%)$ & $18(78.26 \%)$ & 23 \\
\hline p53 & $3(13.04 \%)$ & $10(50 \%)$ & $10(50 \%)$ & $20(86.96 \%)$ & 23 \\
\hline Nilai p (uji Chi square) & \multicolumn{2}{c}{ MDM2 x p p33:0.328 } & & \\
\hline
\end{tabular}

Berbeda dengan hasil penelitian ini dari 18 kasus yang positif, 3 kasus memberikan nilai positif kuat (>50\%) ekspresi MDM2 dan 10 kasus menunjukkan nilai positif kuat ekspresi p53, namun bila dinilai dengan positifitas baik MDM2 maupun p53 menunjukkan hasil yang kurang lebih sama yaitu 78.26\% MDM2 dan 86.96\% p53.

Over ekspresi MDM2 pada tumor dapat dihasilkan karena amplifikasi gen, meningkatnya proses transkripsi dan proses translasi. Pada karsinoma sel skuamosa, over ekspresi MDM2 dapat terjadi karena berbagai faktor seperti interaksi dengan beberapa faktor penekan pertumbuhan seperti suppressor tumor p53, produk pRb, p73, ARF dan meningkatnya kadar p21 (Nang et al., 2013; Rayburn, Zhang, \& Wang, 2005).

Tabel 6. Ekspresi MDM2 dan 533 terhadap Respon Radioterapi pada kanker serviks

\begin{tabular}{cccccc}
\hline & \multicolumn{4}{c}{ Nilai Positif Ekspresi } \\
\cline { 2 - 5 } & & \multicolumn{2}{c}{ MDM2 } & \multicolumn{2}{c}{ p53 } \\
\multicolumn{1}{c}{ Kriteria } & $<50 \%$ & $>50 \%$ & $<50 \%$ & $>50 \%$ \\
\hline \multirow{2}{*}{ Respon } & Komplit & $9(75 \%)$ & $3(25 \%)$ & $8(50 \%)$ & $8(50 \%)$ \\
Nilaip & & $6(100 \%)$ & 0 & $2(50 \%)$ & $2(50 \%)$ \\
\hline
\end{tabular}

\section{EKSPRESI P53 PADA KANKER SERVIKS}

Gen p53 bertindak sebagai gen supresor tumor, mengendalikan siklus sel serta memiliki peran penting dalam proliferasi sel. Mutasi gen ini menghambat aktifitas penekan yang berhubungan dengan perkembangan tumor. Mutasi gen p53 terjadi pada 50\% kanker termasuk kanker serviks (Kim \& Zhao, 2005). Dari data yang diperoleh bahwa 86.96\% (20 kasus) terekspresi p53 dengan diferensiasi sedang sebesar 50\% (8 kasus). Pada beberapa penelitian protein p53 akan terekspresi pada lebih 50\% kasus kanker serviks.

Penelitian lain seperti Prayitno et al. (2005) mendapatkan ekspresi p53 terdapat pada 100\% (19 kasus) 
kanker serviks dengan nilai positif rata-rata 40\%, Troncone et al. (1998) mendapatkan 93.55\%, Tan et al. (2007) mendapatkan 87\% (40 dari 46 kasus) positif terekspresi p53 (Tan et al., 2007). Hasil serupa juga didapatkan oleh Park yaitu $82.05 \%$, sedangkan penelitian yang dilakukan oleh Oka dan Shula kasus yang terekspresi p53 hanya 59.21\% dan 50\% kasus dengan cut off sebesar 10\% (Oka, Suzuki, \& Nakano, 2000; Shailaj, Dass, \& Pujani, 2014).

Hasil ekspresi ini menunjukkan bahwa p53 memainkan peranan penting dalam kanker serviks. Terdapat dua mekanisme berbeda dapat menjelaskan hilangnya fungsi p53 pada kanker serviks yaitu mutasi gen somatik yang mengakibatkan tidak aktif atau meningkatnya kadar protein akibat degradasi yang diperankan oleh E6 onkoprotein HPV tipe 16 dan 18, walaupun pada beberapa penelitian lain tidak terdapat korelasi antara meningkatnya kadar p53 positif dengan ada tidaknya HPV (Kim \& Zhao, 2005).

\section{HUBUNGAN EKSPRESI MDM2 DAN P53 DENGAN RESPON RADIOTERAPI PADA KANKER SERVIK}

Radioterapi merupakan salah satu modalitas pengobatan kanker yang masih dianggap sebagai terapi yang efektif untuk kanker serviks stadium lanjut. Penelitian yang dilakukan oleh Irawan didapat 75\% kasus karsinoma serviks uteri menunjukkan respon radiasi komplit. Resistensi sel kanker terhadap radioterapi serta ekspresi beberapa protein yang berlebihan akan menjadi promotor untuk perkembangan tumor yang menyebabkan terjadinya kegagalan terapi (Irawan, 2008).

Pengaruh keberhasilan ionisasi radioterapi terhadap respon terapi akan berhubungan dengan kerusakan dan perbaikan DNA, apoptosis dan gangguan siklus sel. Jika melihat hal ini keberadaan p53 mutan akan mempengaruhi keberhasilan ionisasi radioterapi sehingga akan mempengaruhi respon radiasi. Hal ini didukung oleh penelitian yang dilakukan oleh Hampson yang menyimpulkan bahwa ekspresi protein E6 yang berlebihan akan mengakibatkan terjadinya radioresistensi Hampson et al. (2001). Song dalam penelitiannya juga membuktikan bahwa protein E6 dan E7 dapat menekan proses hambatan sintesa DNA melalui proses radiasi ionisasi setelah terapi. Peningkatan protein p53 dan p21 sesudah radiasi akan menekan E6, tetapi tidak menekan E7, hal inilah yang akan mempengaruhi respon klinik (Iskandar, Andrijono, \& Supriana, 2008).

Pada penelitian ini 18 kasus yang terekspresi positif MDM2, 12 kasus menunjukkan respon radiasi komplit dan 6 kasus parsial. Perbedaan respon radiasi ini secara statistik tidak menunjukkan hubungan bermakna dengan ekspresi MDM2, begitupula dengan ekspresi p53, pada 20 kasus dengan ekspresi positif p53 terdapat 16 kasus dengan respon komplit dan 4 kasus dengan respon parsial, perbedaan ini juga tidak menunjukkan hubungan bermakna.

Pada kasus dengan respon radiasi komplit yang menunjukan nilai positif MDM2 maupun p53 sejumlah 11 kasus, sedangkan kasus dengan respon parsial yang menunjukkan nilai positif MDM2 dan p53 sejumlah 4 kasus hal ini menggambarkan bahwa nilai positif baik pada MDM2 dan p53 cenderung akan memberikan respon komplit pada terapi radiasi.

Hasil yang sama juga didapat oleh Rotterud et al. ( dalam penelitiannya melakukan pemeriksaan ekspresi protein p53, p21 dan MDM2 secara IHK pada 23 kasus kanker kandung kemih terhadap respon radioterapi. Didapat hasil ekspresi p53 sebesar 47.83\% dan ekspresi MDM2 didapat sebesar 56.52\%, sedangkan hasil radioterapi menunjukkan respon komplit sebesar 60.87\% dan respon parsial sebesar 39.13\%. Kesimpulan dari penelitian ini adalah ekspresi p53 dan MDM2 tidak saling berhubungan dengan respon radiasi Perbedaan mutasi pada p53 mengakibatkan efek yang berbeda pada fungsi protein. Gangguan fungsi tersebut seperti wild type p53 menyebabkan beberapa respon molekuler terhadap radiasi, yang dapat diatasi, hal ini dapat menerangkan mengapa status p53 saja bukan merupakan prediktor kuat dari radiosensitivitas. 
Sedangkan pada penderita kanker paru, Cao, dkk melakukan penelitian dengan menghambat ekspresi MDM2 dapat meningkatkan kadar p53 sehingga banyak sel yang mengalami kematian dan meningkatkan radiosensitifitas. Mekanisme dengan penekanan MDM2 dapat menurunkan pertumbuhan tumor, proses apoptosis dan senescence. Ekspresi p53 penting dalam respon sel kanker pada radiasi. Ekspresi MDM2 menekan p53 yang berfungsi pada siklus sel, apoptosis dan respon terhadap kerusakan DNA (Cao, Shinohara, \& Nierman (2005).

Secara keseluruhan hasil penelitian ini menunjukkan bahwa ekspresi MDM2 dan p53 tidak menunjukkan hubungan bermakna dengan respon radiasi, demikian pula dengan diferensiasi dan stadium. Yang menunjukkan hubungan bermakna adalah antara respon radiasi dengan derajat diferensiasi. Hal ini karena radiasi pada sel erat kaitannya dengan besarnya aktivitas reproduksi sel, lamanya fase mitosis sel dan buruknya diferensiasi sel (Irawan, 2008).

\section{KESIMPULAN}

Ekspresi MDM2 sebesar 78.26\% dan p53 sebesar 86.96\%. Pada respon radiasi komplit ekspresi MDM2 dengan nilai positif $>50 \%$ hanya 3 kasus $(25 \%)$ sedangkan dengan nilai positif $<50 \%$ terdapat 9 kasus $(75 \%)$ sedangkan untuk p53 respon radiasi komplit didapat pada 8 kasus (50\%).

Pada respon parsial ekspresi MDM2 dengan nilai positif $>50 \%$ terdapat pada 6 kasus (100\%) sedangkan untuk p53 terdapat pada 8 kasus (50\%). Hal ini menunjukan bahwa ekspresi MDM2 dengan kisaran $<50 \%$ memiliki kecenderungan respon komplit dibandingkan dengan ekspresi $>50 \%$, lain halnya dengan ekspresi p53 tidak menunjukkan kecenderungan pada nilai positif dan bila diuji secara statistik perbedaan tersebut tidak menunjukan kebermaknaan.

\section{UCAPAN TERIMA KASIH}

Penelitian ini merupakan kerjasama antara PTKMR BATAN, Departemen Patologi Anatomi, Departemen Radioterapi dan Departemen Obstetrik Ginekologi RSCM.

\section{REFERENSI}

WHO. Cancer Cervix. globocan.iarc.fr. 2008

Badan Registrasi Kanker Perhimpunan Dokter Spesialis Patologi Indonesia. Kanker Di Indonesia Tahun 2009 Data Histopatologik. Direktorat Jenderal Pelayanan Medik Departemen Kesehatan RI. Yayasan Kanker Indonesia.. 2013

Aziz MF. Gynecological Cancer in Indonesia. Gynecological Oncology. 2009; 20:8-10.

Bidang Rekam Medik Rumah sakit Kanker Dharmais. Data Rekam Medik per Tahun. Jakarta. Rumah Sakit Dharmais. 2009.

Liu SS, et.al. P73 Expression is Associated with the cellular Radiosensitivity in Cervical Cancer After Radiotherapy. Clin Cancer Res. 2004; 10: 3309-3316.

Tanaka Y, Harima Y.. Oncoprotein Expression Predicts Response to Radiotherapy or Thermoradiotherapy in Human Cervical Cancer. Experimental Oncology. 2000; 22: 52-8. 
Gerl R, Vaux DL. Apoptosis in The Development and Treatment of Cancer. Carcinogenesis. 2005; 26(2): 263-70.

Iwakuma T, Lozano G. MDM2 an Introduction. Mol Cancer Res. 2003; 1: 993-1000.

Shangary S, Wang S. Targeting The MDM2-p53 Interaction for Cancer Therapy. Clin Cancer Res. 2008; 14: 531824.

Klein C, Vassilex LT. Targeting The p53-MDM2 Interaction to Treat Cancer. British Journals of Cancer. 2004; 91:1415-19.

Perry ME. MDM2 in The Response to Radiation. Mol Cancer Res. 2004; 2; 9-19.

Troncone G, et.al. Immunohistochemical Expression of MDM2 and p21 WAFI Invasive Cervical Cancer Correlation with p53 Protein and High Risk HPV Infection. J Clin Pathol. 1998; 51:754-60.

PrayitnoA, et.al.Ekspresiprotein P53, Rb, dan C-Mycpadakankerserviksuteridengan pengecatanimmunohistokimia. Biodiversitas. 2005; 6(3): 157-9.

Cao C, et.al. Murine Double Minute 2 as a Therapeutic Target for Radiation Sensitization of Lung Cancer. Mol Cancer Ther. .2005; 4:1137-45.

Orel K, Cordon C. MDM2 and Prognosis. Mol Cancer Res. 2004; 2:1-8.

Skomedal H, Kristensen GB, Lie AK, Holm R. Aberrant Expression of The Cell Cycle Associated Protein Tp53, MDM2, p21, cdk4, cyclin D1, Rb, and EGFR in Cervical Cancer. Gynecologic Oncology. 1999;. 73, 223-8

Park In-Seo, et. all. Immunohistochemical Expression of p53, p21, and mdm2 proteins in Human Papillomavirus Positive and Negative Invasive Uterine Cervical Carcinomas. The Korean Journal of Pathology. 2001; 35: 212-9

Hong JH, Chen MH, Lin FJ, Tang S. Prognostic Assessment of Tumor regression after External Irradiation for Cervical Cancer. Int. J Radiation Oncology Biol Phys. 1992; 22, 913-7.

Vidyasagar MS, K. Maheedhar, BM. Vadhiraja, Donald J. Fermendes, VB Kartha, C. Murali Krishna. Prediction of Radiotherapy Response in Cervix Cancer by Raman Spectroscopy: A Pilot Study. Biopolymers. 2008; 89: $530-7$

Dahlan M. Sopiyudin. Statistik Untuk Kedokteran Kesehatan. Salemba Medika. Jakarta. 2009

Romus Ilhami, FX Ediati Triningsing, Sagiri Mangunsudirjo, Ahmad Harijadi. Clinicopathology Signifivance of p53 and p63 Expression in Indonesia Cervical Squamous Cell Carcinomas. Asian Pacific Journal of Cancer Prevention. 2013; 14.

Saxena Angela, Catheryn Yashar, Douglas D Taylor, Cicek Gercel Taylor. Cellular Response to Chemotherapy and Radiation in Cervical Cancer. American Journal of Obstetrics and Gynecology. 2005; 1399-403

Nakano Takashi, Tatsuya Ohno, Hitoshi Ishikawa, Yoshiyuka Suzuki, Takeo Takashi. Current Advancement in Radiation Theraphy for Uterine Cervical cancer. Journal Radiation Research. 2010; 51: 1-8.

Kersemaekers AMF, Flueren GJ, Kenter GG. Oncogene Alteration in carcinomas of the Uterinr Cervix: Overexpression of the Epidermal Growth Factor Receptor Is Associated with Poor Prognosis. Clin Cancer Res. 1999; 5: 557-86.

Nag S, Qin J, Srivenugopal K, Wang M, Zhang R. The MDM2-p53 pathway revisited. 2013; 27: 1-18 
Rayburn E, Zhang R, He J, Wang H.. MDM2 and Human Malignancies: Expression, Clinical Pathology, Prognostic Makers, and implification for Chemotherapy. Current Drug Target. 2005; 5: 27-41.

Young Tae Kim, Min Zhao. Aberrant Cell Cycle Regulation in Cervical Carcinoma. Yosei Medical Journal. 2005; 46 (5): 597-613.

Tan GC, Sharifah NA, Salwati S, Shiran MS, Hatta AZ, Ngho. Immunohistochemical Study of p53 Expression in Premalignant and Malignant Cervical Neoplasma. Medical and Health. 2007; 2(2): 125-132.

Oka Kuniyaki, Yoshiyuki Suzuki, Takashi Nakano. Expression of p27 and p53 in Cervical Squamous Cell Carcinoma Patients Treated with Radiotherapy Alone. American Cancer Society. 2000; 88: (12);2766-73.

Shukla Shailaja, Jasmita Dass, Mukta Pujani. P53 and Bcl2 Expression in Malignant and Premalignant Lession of Uterine Cervix and Their Correlation with Human Papilloma Virus 16 and 18. South Asian Journal Cancer. 2014; 3 (1): 48-53.

Irawan. Hubungan Nilai AgNor Pra dan Pasca Kemoradiasi dengan Respon Radiasi pada Penderita karsinoma Epidermoid Seriks Uteri Stadium Lanjut. Tesis. Universitas Diponegoro. 2008

Hampson L, El Hady ES, Moore JU, Kithener H, Ian N. The HPV 16 E6 and E7 Protein and Radiation Resistance of Cervical Carcinoma. FASEB. 2001; 5: (10).

Iskandar, Andrijono, N.Supriana. Uji Klinik Kemoradiasi disbanding Radiasi Terhadap Respon Infeksi HPV dan Respon Klinik Pada arsinoma Sel Skuamos Serviks Uteri. Maj, Obstet Ginekologi Indonesia. 2008; 32 (4).

Rooterud R, Berner A, Holm R, Skovlund E, Fossa D. p53, p21 and MDM2 Expression VS the response to radiotherapy in transitional cell carcinoma of bladder. BJU International. 2001; 88: 202-8.

Cao C, Shinohara ET, Niermann. Murine double minute 2 as a therapeutic target for radiation sensitization of lung cancer. Molecular cancer Therapeutics. 2005; 5(4):1137-45 